\title{
Systemic use of metronidazole in the treatment of chronic periodontitis: a pilot study using clinical, microbiological, and enzymatic evaluation
}

\section{Utilização sistêmica do metronidazol no tratamento da doença periodontal crônica: estudo piloto sobre avaliação clínica, microbiológica e enzimática}

\author{
Solange Alonso Vergani* \\ Emílio Barbosa e Silva* \\ Adriana Helena Vinholis* \\ Rosemary Adriana Chiérici Marcantonio**
}

\begin{abstract}
The aim of the present parallel, double-blind investigation was to evaluate the effect of using systemic metronidazole alone or associated to scaling and root planing on adult chronic periodontal disease, monitored at baseline, 30, 60 and 90 days. Twelve subjects were divided into three groups: the first group (Group I - 22 sites) was submitted to scaling and root planing (SRP) alone; the second group (Group II - 30 sites) received SRP and $250 \mathrm{mg}$ of metronidazole ( 3 times a day for 10 days), and the third group (Group III - 31 sites) was treated with metronidazole alone. The clinical parameters evaluated were probing depth (PD), clinical attachment level (CAL), plaque index (PII), gingival index (GI) and bleeding upon probing (BP). Microbiological (BANA test) and enzymatic (Pocket Watch) tests were also performed. All three proposed treatments produced significant improvements in clinical conditions of subjects, from baseline, 30, 60 and 90-day period, except for clinical attachment level. The results obtained by microbiological and enzymatic tests did not show statistical differences among the groups for the 90-day period $(r=0.7924$ and $r=0.7757$, respectively). In relation to clinical parameters, statistical differences among groups were observed only for the gingival index $(\mathrm{p}=0.0261)$ between Groups I and II, and probing depth $(p=0.0124)$ between Group I and the others. We conclude that the use of systemic metronidazole did not produce additional effects on the microbiological conditions of these patients with chronic periodontal disease.
\end{abstract}

DESCRIPTORS: Periodontal diseases; Metronidazole; Aspartate aminotransferase.

\begin{abstract}
RESUMO: O objetivo do presente estudo paralelo, duplo-cego foi o de avaliar os efeitos do uso do metronidazol sistêmico, associado ou não à raspagem e ao alisamento radicular, sobre a doença periodontal crônica do adulto, observados inicialmente, aos 30, 60 e 90 dias. Foram selecionados 12 pacientes, distribuídos em 3 grupos: o primeiro grupo (Grupo I - 22 sítios) foi submetido a raspagem e alisamento radicular (RAR) somente; o segundo grupo (Grupo II - 30 sítios) recebeu RAR e $250 \mathrm{mg}$ de metronidazol (3 X/dia, durante 10 dias); o terceiro grupo (Grupo III - 31 sítios) foi tratado somente com metronidazol. Os parâmetros clínicos avaliados foram profundidade de sondagem (PS), nível de inserção clínica (NI), índices de placa (IPl) e gengival (IG) e sangramento à sondagem (SS). Os pacientes foram submetidos, ainda, à análise microbiológica (BANA) e enzimática ("Pocket Watch"). Os três tratamentos propostos melhoraram significativamente as condições clínicas dos pacientes no início, e nos períodos de 30, 60 e 90 dias, exceto para o nível de inserção clínica. As análises microbiológica e enzimática não apresentaram diferença estatística entre os três grupos para o periodo de 90 dias ( $\mathrm{r}=0,7924$ e $\mathrm{r}=0,7757$, respectivamente). Já nos parâmetros clínicos, encontrou-se diferença estatística somente para o índice gengival $(p=0,0261)$ entre os Grupos I e II e, para a profundidade de sondagem, $(p=0,0124)$ entre o Grupo I e os outros grupos. Pode-se concluir que o uso do metronidazol sistêmico não produziu efeitos adicionais na microbiota desses pacientes com doença periodontal crônica.

DESCRITORES: Doenças periodontais; Metronidazol; Aspartato aminotransferase.
\end{abstract}

\section{INTRODUCTION}

The treatment of periodontal diseases has been carried out by means of mechanical elimi- nation of supra- and subgingival biofilm. This procedure alters the biofilm composition, reduces

\footnotetext{
*MS; **PhD - Department of Periodontology, School of Dentistry of Araraquara, São Paulo State University.
} 
Vergani SA, Silva EB, Vinholis AH, Marcantonio RAC. Systemic use of metronidazole in the treatment of chronic periodontitis: a pilot study using clinical, microbiological, and enzymatic evaluation. Braz Oral Res 2004;18(2):121-7.

the amount of microorganisms and prevents recolonization $^{2}$. Mechanical debridement may fail to remove pathogenic organisms because of their location in sub-epithelial gingival tissue, crevicular epithelial cells, collagenous substrata, altered cementum and radicular dentinal tubuli, subgingival hard deposits or furcations or other anatomic features that complicate adequate instrumentation. Moreover, periodontal pathogens frequently colonize oral mucosa, tongue dorsum, tonsils and other oral domains and may translocate from nonperiodontal sites to periodontal crevices ${ }^{15}$.

According to Loesche et al. ${ }^{7}$ (1992) most periodontal pathogens are anaerobic, which indicates that most periodontal diseases can be diagnosed and treated as anaerobic infections.

During the past two decades, dentists and microbiologists have adopted periodontal antibiotic therapy based on bacterial specificity in periodontitis ${ }^{15}$. Thus, the control of the number of periodontal pathogenic microorganisms would facilitate the control of the disease for an extended period of time. The use of chemical agents in the control of these periodontal microorganisms can provide more effective and predictable clinical results, as they are less expensive and more easily accepted by many patients than other complex and traumatic treatments, such as periodontal surgeries ${ }^{14}$.

Metronidazole is a bactericidal antimicrobial agent indicated for use against a restricted number of anaerobic organisms, safe for human use, which has been widely studied but demonstrates some contradictory results. This diversity in results may be related to the use of the drug in cases where there is no proper indication or the anaerobic infection has not been established by precise diagnosis ${ }^{7}$.

Diagnostic data obtained by an accurate history and by the performance of a disciplined clinical examination are usually much more powerful than anything that can be gleaned from the diagnostic laboratory. Yet, sometimes, diagnostic information can be very useful to improve clinical management. In this study, the microbiological (BANA) and enzymatic (Pocket Watch) tests were used to confirm the presence of the periodontal pathogen microorganisms and the presence of inflammation on sites treated by the use of systemic metronidazole, with and without scaling and root planing, in adult patients with chronic periodontitis.

\section{MATERIAL AND METHODS}

Twelve non-smoker subjects, aged between 29 and 63 years (mean 46 years), were selected (six men and six women), and a total of 83 sites were evaluated. All subjects presented chronic periodontal disease and good systemic health conditions. They also presented at least four periodontal sites in anterior or single-rooted teeth with probing depth $\geq 5 \mathrm{~mm}$. All participants were informed about the nature of the study and gave their consent by signing an informed consent form, whose written content had been previously approved by the Ethics Committee of the School of Dentistry of Araraquara, São Paulo State University.

After the selection of the sites, the procedures described in Figure 1 were followed.

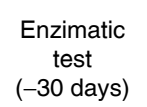

test
(-30 days)

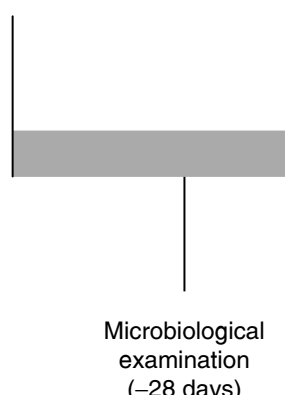

(-28 days)
Clinical

examination

(-21 days)
Baseline $2^{\text {nd }}$ re-evaluation

(clinical)

FIGURE 1 - Scheme of the treatment procedure. 
Vergani SA, Silva EB, Vinholis AH, Marcantonio RAC. Systemic use of metronidazole in the treatment of chronic periodontitis: a pilot study using clinical, microbiological, and enzymatic evaluation. Braz Oral Res 2004;18(2):121-7.

In the present investigation the enzymatic test was performed using the Pocket Watch (Steri-oss ${ }^{\circledR}$, Yorba Linda, California, USA). Before the sampling of the sites, the gingival area was isolated from saliva by applying cotton rolls and the sampled area was dried gently with compressed air. Then the visible supragingival plaque was removed with a periodontal scaler and dental floss. Endodontic sterilized paper points (n. 20-30, Diadent absorbent paper points, Burnaby, BC, Canada) were then inserted into the crevice and moved apically until mild resistance was felt and left in place for 30 seconds. The paper points were placed into the test-kit cocoons with a liquid solution afterwards. As per the manufacturer's instructions, the results were obtained after a period ranging from five to seven minutes. The results were visually evaluated, and were considered negative when the solution remained violet and positive when the solution turned pink.

The microbiological test was performed with the BANA test (Perioscan ${ }^{\mathrm{TM}}$, Oral $\mathrm{B}^{\circledR}$ Laboratories, Belmont, California, USA). After the removal of the supragingival biofilm, a sample of the subgingival biofilm was collected with a sterile periodontal curette and placed on the inferior part of the test card. The cards were then placed in the heating unit for fifteen minutes. The results were obtained by observing the color of the cards: positive when it turned blue (regardless of the intensity) and negative in absence of color.

During the selection of the patients, probing guides were manufactured using $1.5 \mathrm{~mm}$ thick vacuum-compressed acrylic plaques (Bio-Art ${ }^{\circledR}$ Equipamentos Odontológicos Ltda. São Paulo, Brazil) as a way to standardize probe position during clinical exams.

All clinical exams were performed by the same examiner, a periodontologist, who was previously calibrated (data not shown) and blinded to treatments. The clinical parameters evaluated during the exam were plaque index ${ }^{13}$, gingival index ${ }^{5}$, bleeding on probing (detected after 30 seconds of probe insertion into the periodontal pocket), probing depth (PD) and clinical attachment level (CAL) - all obtained by a computerized probe under constant pressure (Florida Probe ${ }^{\circledR}$ Corporation, Gainesville, Florida, USA).

One week after the initial exams, the roots of the teeth not involved in the study were scaled and root planed. Also, the patients received individually oral hygiene instructions.
After these procedures, the patients were randomly divided into three groups of four patients each:

- Group I - 4 patients, 22 sites - scaling and root planing procedures (SRP).

- Group II - 4 patients, 30 sites - SRP procedures plus $250 \mathrm{mg}$ of systemic metronidazole (Flagyl ${ }^{\circledR}$, Rhodia Farma, São Paulo, Brazil), three times a day, for 10 days.

- Group III - 4 patients, 31 sites - only systemic metronidazole, following the same therapeutic outline employed for the second group.

A single operator, different from the examiner that evaluated the clinical parameters, followed the scaling and root planing procedures.

For the subjects in the second group, the use of antibiotics and scaling and root planing began simultaneously. In Group III it happened immediately after the end of scaling and root planing of the teeth which were not involved in the study. The patients were seen every week and plaque control and oral hygiene instructions were reinforced.

All clinical parameters were repeated after 30, 60 and 90 days from baseline. The enzymatic test and the microbiological evaluation were repeated during the last exam, 90 days after baseline. The Pocket Watch test was only conducted at the sites with the deepest initial probing depths.

For the analysis of the results obtained from the BANA test, from the enzymatic test and from bleeding on probing, the $Z$ test for differences between two sampling proportions was used. During the application of this statistical test, the frequency of the positive results observed during the different periods was considered. Pearson's correlation test was used to analyze the data from both the BANA and enzymatic tests to verify the existence of correlation among the treatment types. Friedman's complementary test was adopted for bleeding on probing.

\section{RESULTS}

Significant interactions between groups and periods were not found. This is why they were evaluated independently.

Compared with the baseline, all treatments resulted in a significant decrease of positive results from the enzymatic and BANA tests (Table 1), but Pearson's complementary test was unable to detect any statistically significant difference among the types of treatment adopted. 
Vergani SA, Silva EB, Vinholis AH, Marcantonio RAC. Systemic use of metronidazole in the treatment of chronic periodontitis: a pilot study using clinical, microbiological, and enzymatic evaluation. Braz Oral Res 2004;18(2):121-7.

TABLE 1 - Frequency of periodontal sites with positive reactivity to microbiological (BANA) and enzymatic (Pocket Watch) tests at baseline and after 90 days from the beginning of treatment.

\begin{tabular}{|c|c|c|c|c|c|c|c|c|}
\hline \multirow{3}{*}{ Treatment } & \multicolumn{4}{|c|}{ BANA test } & \multicolumn{4}{|c|}{ Pocket Watch test } \\
\hline & \multicolumn{2}{|c|}{ Baseline } & \multicolumn{2}{|c|}{90 days } & \multicolumn{2}{|c|}{ Baseline } & \multicolumn{2}{|c|}{90 days } \\
\hline & $\mathrm{N}$ & $\%$ & $\mathrm{~N}$ & $\%$ & $\mathrm{~N}$ & $\%$ & $\mathrm{~N}$ & $\%$ \\
\hline $\mathrm{SRP}+$ metronidazole (Group II) & 23 & 76.7 & 0 & $0.0^{*}$ & 24 & 80.0 & 5 & $27.8^{*}$ \\
\hline Metronidazole (Group III) & 28 & 90.3 & 0 & $0.0^{*}$ & 26 & 83.9 & 5 & $38.5^{*}$ \\
\hline
\end{tabular}

*Intra-group statistically significant differences. SRP: scaling and root planing.

TABLE 2 - Frequency of periodontal sites with bleeding upon probing at baseline and after different periods of time.

\begin{tabular}{|c|c|c|c|c|c|c|}
\hline \multirow{3}{*}{ Treatment } & \multicolumn{6}{|c|}{ Time (days) } \\
\hline & \multicolumn{2}{|c|}{$0-30$} & \multicolumn{2}{|c|}{$0-60$} & \multicolumn{2}{|c|}{$0-90$} \\
\hline & $\mathrm{N}$ & $\%$ & $\mathrm{~N}$ & $\%$ & $\mathrm{~N}$ & $\%$ \\
\hline SRP + metronidazole (Group II) & 12 & $40.0^{*}$ & 9 & $30.0^{*}$ & 11 & $36.7^{*}$ \\
\hline Metronidazole (Group III) & 18 & 58.1 & 17 & $54.8^{*}$ & 9 & $29.0 *$ \\
\hline
\end{tabular}

*Intra-group statistically significant differences among periods. SRP: scaling and root planing.

Bleeding on probing fell significantly for all the re-evaluation periods, except for the first 30-day interval of Group III. However, Friedman's complementary test was unable to detect significant differences among the treated groups (Table 2).

The statistical model of the two-criterion parametric variance analysis (ANOVA) was used with the precision of 0.05 for the analysis of the results related to the probing depth, the clinical attachment level, the gingival index and the plaque index. For the cases where significant differences were found, Scheffé's complementary test was used to identify them. In this case, the results were analyzed in pairs until the interval where the differences were observed.

The results from the evaluation of plaque and gingival index are presented in Table 3.

No inter-groups significant differences were found in plaque index results. However, differences $(p<0.05)$ were detected when the baseline period and the other periods (30, 60 and 90 days) were considered.

The analysis of gingival index demonstrated significant differences between Group I and Group II $(p<0.05)$ and highly significant differences $(p<0.0001)$ between the baseline and the 60-day period and the baseline and the 90-day period.
In relation to the probing depth (Table 4), significant statistical differences were observed among Group I and the two other groups (II and III). These differences were also observed for the various periods of experimental data collection (30, 60 and 90 days).

No significant differences $(p>0.05)$ were found for clinical attachment level in any of the clinical parameters analyzed (Table 4).

\section{DISCUSSION}

A few limitations of this study are evident. One is the size of the sample, although the total number of sites is in agreement with the literature. Another one is that, for the type of disease evaluated, systemic antibiotics may not be the best indicated therapy. According to Gusberti et al. ${ }^{3}$ (1988) and Winkel et al. ${ }^{18}$ (1997) the use of systemic metronidazole in patients with aggressive forms of periodontitis promotes more favorable results, and such differences remained for more than nine months.

It is important to remember that the BANA test also presents some limitations. Its ability to detect anaerobic infection is limited to the presence of four species of periodontal pathogens, and 
Vergani SA, Silva EB, Vinholis AH, Marcantonio RAC. Systemic use of metronidazole in the treatment of chronic periodontitis: a pilot study using clinical, microbiological, and enzymatic evaluation. Braz Oral Res 2004;18(2):121-7.

TABLE 3 - Means from values of plaque and gingival indexes from subjects evaluated before and after 30, 60 and 90 days from the beginning of three different periodontal treatments.

\begin{tabular}{|c|c|c|c|}
\hline Treatment & $\begin{array}{l}\text { Time } \\
\text { (days) }\end{array}$ & $\begin{array}{l}\text { Plaque } \\
\text { index }\end{array}$ & $\begin{array}{l}\text { Gingival } \\
\text { index }\end{array}$ \\
\hline \multirow{4}{*}{$\begin{array}{l}\text { SRP } \\
\text { (Group I) }\end{array}$} & 0 & 1.95 & 1.85 \\
\hline & 30 & $1.40^{*}$ & 1.45 \\
\hline & 60 & $1.37^{*}$ & $1.27^{*}$ \\
\hline & 90 & $1.17^{*}$ & $1.17^{*}$ \\
\hline \multirow{4}{*}{$\begin{array}{l}\text { SRP + } \\
\text { metronidazole } \\
\text { (Group II) }\end{array}$} & 0 & 2.25 & 1.87 \\
\hline & 30 & $0.87^{*}$ & 0.90 \\
\hline & 60 & $0.67^{*}$ & $0.40^{*}$ \\
\hline & 90 & $0.70^{*}$ & $0.55^{*}$ \\
\hline \multirow{4}{*}{$\begin{array}{l}\text { Metronidazole } \\
\text { (Group III) }\end{array}$} & 0 & 2.10 & 1.82 \\
\hline & 30 & $1.52^{*}$ & 1.42 \\
\hline & 60 & $1.55^{*}$ & $1.05^{*}$ \\
\hline & 90 & $1.05^{*}$ & $0.80^{*}$ \\
\hline
\end{tabular}

*Statistically significant difference between examinations for plaque index: 0 versus 30 days, 0 versus 60 days, 0 versus 90 days $(\mathrm{p}<0.05)$ - for gingival index: 0 versus 60,0 versus 90 days $(p<0.0001)$. There was statistically significant differences between groups I and II ( $p<0.05)$. SRP: scaling and root planing.

it is impossible to identify which one or ones are present.

The demonstration of specificity in periodontitis allows the dentist to direct therapy towards the elimination or suppression of the periodontal pathogens in antimicrobial treatments. Obligate anaerobic microorganisms are associated with destructive periodontitis and metronidazole has excellent activity against anaerobic species of subgingival microbiota. In this study, the effects of systemic metronidazole use, whether associated or not to scaling and root planing procedures, on the treatment of adult patients with chronic periodontitis were evaluated.

Pocket Watch (Steri-oss ${ }^{\circledR}$, Yorba Linda, California, USA) is a qualitative test to determine the presence of large amounts of aspartate aminotransferase (AST) in the gingival fluid. AST is a cytoplasmic enzyme present in many body tissues. The extracellular release of AST is associated with cell damage and death.

Treponema denticola, Porphyromonas gingivalis and Bacteroides forsythus are frequently considered potential periodontal pathogens. They possess an enzyme that hydrolyzes the synthetic substrate benzoyl-DL-arginine-naphthylamide (BANA). The
TABLE 4 - Means from values of probing depth (in $\mathrm{mm}$ ) and variation of clinical attachment level (in $\mathrm{mm}$ ), evaluated before and after 30, 60 and 90 days from the beginning of different treatments.

\begin{tabular}{l|c|c|c}
\hline \hline \multirow{4}{*}{ Treatment } & $\begin{array}{c}\text { Time } \\
\text { (days) }\end{array}$ & $\begin{array}{c}\text { Probing } \\
\text { depth }\end{array}$ & $\begin{array}{c}\text { Clinical } \\
\text { attachment level }\end{array}$ \\
\hline \multirow{3}{*}{$\begin{array}{l}\text { SRP } \\
\text { (Group I) }\end{array}$} & 0 & 6.22 & 0.00 \\
\cline { 2 - 4 } & 30 & $5.57^{*}$ & 0.97 \\
\cline { 2 - 4 } & 60 & $5.37^{*}$ & 0.96 \\
\hline \multirow{3}{*}{$\begin{array}{l}\text { SRP + } \\
\text { metronidazole }\end{array}$} & 90 & $5.20^{*}$ & 0.95 \\
\cline { 2 - 4 } Group II) & 60 & 6.17 & 0.00 \\
\cline { 2 - 4 } & 90 & $4.52^{*}$ & 0.98 \\
\hline \multirow{3}{*}{$\begin{array}{l}\text { Metronidazole } \\
\text { (Group III) }\end{array}$} & 30 & $5.17^{*}$ & 0.92 \\
\cline { 2 - 4 } & 60 & $4.20^{*}$ & 0.94 \\
\cline { 2 - 4 } & 90 & $4.00^{*}$ & 0.00 \\
\hline \hline
\end{tabular}

*Statistically significant difference between examinations for probing depth: 0 versus 30 days, 0 versus 60 days, 0 versus 90 days $(\mathrm{p}<0.05)$. There was statistically significant differences between groups I and II, and between I and III $(\mathrm{p}<0.05)$. SRP: scaling and root planing.

BANA test is considered useful in improving the diagnosis and/or treatment of periodontal disease.

The BANA test was used to conduct a diagnosis of an anaerobic infection and to verify the ability of metronidazole to achieve clinical benefits for the patients that were treated by scaling and root planing alone.

After 90 days, all treatments resulted in a decrease in the percentage of sites with BANA-positive results, without significant difference among the treatments accomplished.

BANA-positive results observed in the present study decrease in 87 percent of the patients treated by scaling and root planing alone and in 100 percent for the two groups in which metronidazole was administered. These results are in agreement with those found by Loesche et al. ${ }^{6}$ (1990) where, in patients treated with metronidazole plus scaling and root planing, 70 percent of BANA-positive results converted to BANA-negative, whereas in the positive control group (scaling and root planing) it happened in 53 percent of the cases. GierdrysLeeper et al. ${ }^{2}$ (1985) demonstrated that treatment with metronidazole, with or without curettage, had only a transient effect upon the subgingival microbiota, but the repopulation of motile forms 
Vergani SA, Silva EB, Vinholis AH, Marcantonio RAC. Systemic use of metronidazole in the treatment of chronic periodontitis: a pilot study using clinical, microbiological, and enzymatic evaluation. Braz Oral Res 2004;18(2):121-7.

occurred earlier in metronidazole-only sites. The results obtained in the present study did not show differences among treatments. This fact can be explained by the interval between analyses: after 90 days, differences among the number of recolonization microorganisms no longer exist; or the BANA test is not sensitive enough to capture those differences.

Plaque control promotes the retraction of the swollen gingival tissue present at the start of the experimental period and changed it into firmer, healthier tissue of smaller volume. In the present study, the decrease of gingival inflammation is shown by the reduction in plaque and gingival indexes, probing depths and by the changes in clinical attachment level.

The general clinical periodontal condition improved in all groups. Bleeding upon probing showed reduction during the experimental period, without differences regardless of the type of treatment. It is interesting to note that Lekovic et al. ${ }^{4}$ (1983), who also evaluated the systemic therapy with metronidazole alone and in conjunction with scaling and root planing, reported a higher decrease of bleeding in patients who were submitted to metronidazole and scaling and root planing procedures than in ones treated with the systemic therapy alone. This may be due to the difference in the periods of evaluation, which was of only 4 weeks in their study and about 12 weeks in the present study.

The reduction in probing depth was more significant in Group I than in the other two groups. The average demonstrated that Group I had the largest number of deep pockets and the other two did not have significant differences. This is consistent with the findings of Loesche et al. ${ }^{8}$ (1984), van Oosten et al. ${ }^{16}$ (1987), Walsh et al. ${ }^{17}$ (1986) and also Lekovic et al. ${ }^{4}$ (1983), where only in subjects treated by scaling and root planing plus metronidazole significant differences were found.

For the variation of clinical attachment level, no statistically significant differences were observed. Such results are in agreement with Sáxen, Asikainen $^{12}$ (1993) and Noyan et al. ${ }^{9}$ (1997). It is possible that the absence of statistical differences observed in this parameter means that the reductions in pocket depth were followed by gingival recession.

In relation to plaque index, no significant differences were observed among treatments, only a statistically significant reduction after baseline. These results are in agreement with those obtained by Lekovic et al..$^{4}$ (1983) and Noyan et al..$^{9}$ (1997), where the reductions in the plaque index were not associated to the treatment types employed. During the experimental period, all patients received instructions of oral hygiene and plaque control. These procedures promoted a decrease in plaque accumulation and may explain the decrease observed after baseline.

The gingival index score decreased and the changes were statistically different between Group I and II and also between the baseline and the last two periods. These results are in agreement with those found by Walsh et al. ${ }^{17}$ (1986). Sáxen, Asikainen $^{12}$ (1993) and Palmer et al. ${ }^{10}$ (1999) also observed a reduction in gingival inflammation, although no differences were found among the treatment types used. This reduction in gingival inflammation seems to be directly associated with a decrease in the plaque index.

The gingival inflammation reduction promoted a decrease in the amount of gingival fluid, which may help the effects of the systemic therapy. It also increased the concentration of the drug in the plasma ${ }^{1}$ justifying the results observed in the group where the two therapies were associated.

In a similar way, the decrease in the number of positive results for Pocket Watch indicates an improvement promoted by the treatments. However, no significant differences were found among them. The enzyme aspartate aminotransferase is normally confined to the cytoplasm of cells, but it is released on cell death. The decrease in positive results for this test is probably related to the decrease of gingival inflammation after treatments employed and plaque control performed by the subjects. Persson et al. ${ }^{11}$ (1990) demonstrated a statistically significant association between the development and the resolution of induced periodontal inflammation, showing that the test can be used to assess the presence and extent of periodontal inflammation.

\section{CONCLUSIONS}

Within the limits of this study, based on the results obtained, it was concluded that all treatments resulted in an improvement of the parameters evaluated, except for clinical attachment level. Additional effects in the use of systemic metronidazole relative to microbiological condition of the subjects could not be observed, and the use of this drug in patients with chronic periodontal disease seems to be unjustified. 
Vergani SA, Silva EB, Vinholis AH, Marcantonio RAC. Systemic use of metronidazole in the treatment of chronic periodontitis: a pilot study using clinical, microbiological, and enzymatic evaluation. Braz Oral Res 2004;18(2):121-7.

\section{ACKNOWLEDGMENTS}

To CNPq (National Council for Scientific and Technological Development) for financial support, to Prof. Geraldo Maia Campos and Prof. Sergio

\section{REFERENCES}

1. Eisenberg L, Suchow R, Coles RS, Deasy MJ. The effects of metronidazole on clinical and microbiologic parameters of periodontal disease. Clin Prev Dent 1991;13:28-34.

2. Giedrys-Leeper E, Selipsky H, Williams BL. Effects of shortterm administration of metronidazole on the subgingival microflora. J Clin Periodontol 1985;12:797-814.

3. Gusberti FA, Syed SA, Lang NP. Combined antibiotic (metronidazole) and mechanical treatment effects on the subgingival bacterial flora of sites with recurrent periodontal disease. J Clin Periodontol 1988;15:353-9.

4. Lekovic V, Kenney EB, Carranza FA Jr, Endres B. The effect of metronidazole on human periodontal disease. A clinical and bacteriological study. J Periodontol 1983;54:476-80.

5. Löe $H$. The gingival index, the plaque index and the retention index systems. J Periodontol 1967;38:610-6.

6. Loesche WJ, Giordano J, Hujoel PP. The utility of the BANA test for monitoring anaerobic infections due to spirochetes (Treponema denticola) in periodontal disease. J Dent Res 1990;69:1696-702.

7. Loesche WJ, Giordano JR, Hujoel P, Schwarcz J, Smith BA. Metronidazole in periodontitis: reduced need for surgery. J Clin Periodontol 1992;19:103-12.

8. Loesche WJ, Syed SA, Morrison EC, Kerry GA, Higgins T, Stoll J. Metronidazole in periodontitis. I. Clinical and bacteriological results after 15 to 30 weeks. J Periodontol 1984;55:325-35.

9. Noyan Ü, Yilmaz S, Kuru B, Kadir T, Acar O, Büget E. A clinical and microbiological evaluation of systemic and local metronidazole delivery in adult periodontitis patients. J Clin Periodontol 1997;24:158-65.

10. Palmer RM, Mattews JP, Wilson RF. Non-surgical periodontal treatment with and without adjunctive metro-
Arthur de Oliveira Campos for statistical analysis and to Solange Aranha for English review.

nidazole in smokers and non-smokers. J Clin Periodontol 1999;26:158-63.

11. Persson GR, DeRouen TA, Page RC. Relationship between levels of aspartate aminotrasferase in gingival crevicular fluid and gingival inflammation. J Periodontal Res 1990;25:17-24.

12. Sáxen L, Asikainen S. Metronidazole in the treatment of localized juvenile periodontitis. J Clin Periodontol 1993;20:166-71.

13. Silness P, Löe H. Periodontal disease in pregnancy. II. Correlation between oral hygiene and periodontal condition. Acta Odontol Scand 1964;24:747-59.

14. Slots J, Rams TE. Antibiotics in periodontal therapy: advantages and disadvantages. J Clin Periodontol 1990; 17:479-93.

15. Slots J, Ting M. Systemic antibiotics in the treatment of periodontal disease. Periodontol 2000 2002;28:10676.

16. van Oosten MAC, Mikx FHM, Renggli HH. Microbial and clinical measurements of periodontal pockets during sequential periods of non-treatment, mechanical debridement and metronidazole therapy. J Clin Periodontol 1987;14:197-204.

17. Walsh MM, Buchanan SA, Hoover CI, Newbrun E, Taggart EJ, Armitage GC, et al. Clinical and microbiologic effects of single-dose metronidazole or scaling and root planing in treatment of adult periodontitis. J Clin Periodontol 1986;13:151-7.

18. Winkel EG, van Winkelhoff AJ, Timmerman MF, Vangsted T, van Der Velden U. Effects of metronidazole in patients with "refractory" periodontitis associated with Bacteroides forsythus. J Clin Periodontol 1997;24:573-9. 